\title{
PERBEDAAN PENGARUH ANTARA LATIHAN GERAK TARI JAWA TENGAH MODIFIKASI DENGAN LATIHAN PROPRIOSEPTIF TERHADAP KESEIMBANGAN DINAMIS PADA LANSIA
}

\author{
Catarina Budi $P^{1}$, RA Tuty Kuswardhani ${ }^{2}$, S. Indra Lesmana ${ }^{3}$, I Putu Gede Adiatmika ${ }^{4}$, \\ J. Alex Pangkahila ${ }^{5}$, Ni Wayan Tianing ${ }^{6}$ \\ ${ }^{1}$ Program Studi Magister Fisiologi Keolahragaan Universitas Udayana, Denpasar \\ ${ }^{2}$ Divisi Geriatri, Dept./KSM Penyakit Dalam FK Unud/ RSUP Sanglah, Denpasar \\ ${ }^{3}$ Fakultas Fisioterapi Universitas Esa Unggul, Jakarta \\ ${ }^{4,5}$ Fakultas Kedokteran Universitas Udayana, Denpasar \\ ${ }^{6}$ Program Studi Fisioterapi, Universitas Udayana, Denpasar
}

\section{ABSTRAK}

E-mail: katrin.ifiklaten@gmail.com

Pendahuluan: Proses penuaan dialami semua manusia secara alamiah. Penuaan ditandai perubahan yang terjadi pada sistem-sistem tubuh manusia. Sistem muskuloskeletal, sistem persyarafan, sistem kardiovaskuler, dan pancaindera mengalami perubahan-perubahan yang berdampak pada timbulnya gangguan pada lansia seperti gangguan keseimbangan, gangguan koordinasi, serta ganggua kognitif. Hal-hal tersebut menimbulkan berbagai permasalahan pada lansia, terutama masalah keseimbangan yang berdampak meninggiya resiko jatuh, penurunan performa akifitas hingga berkurangnya produkifitas lansia bahkan kematian. Latihan yang baik untuk meningkatkan keseimbangan lansia adalah latihan aktifitas dinamis (dynamic activities) antara lain latihan tari Jawa Tengah modifikasi dan latihan proprioseptif. Tujuan: (1) untuk membuktikan bahwa latihan tari Jawa Tengah modifikasi meningkatkan keseimbangan dinamis pada lansia, (2) membuktikan bahwa latihan proprioseptif dapat meningkatan keseimbangan dinamis pada lansia, dan (3) Antara latihan tari Jawa Tengah modifikasi dan latihan proprioseptif manakah yang lebih meningkatkan keseimbangan dinamis pada lansia. Metode: dilakukan penelitian terhadap komunitas lansia pada paguyuban Simeon-Hanna di Gereja Maria Assumpa Klaten. Penelitian melibatkan dua kelompok perlakuan yaitu kelompok dengan intervensi latihan tari Jawa Tengah modifikasi dan kelompok latihan .proprioseptif. Penelitian dilakukan selama 8 minggu dengan frekwensi 2 kali perminggu dan durasi 55 menit dalam satu sesi latihan. Alat ukur untuk keseimbangan diamis dan resiko jatuh menggunakan Time Up and Go (TUG) test. Hasil penelitian didapatkan: (1) Terdapat peningkatan keseimbangan dinamis pada kelompok latihan tari jawa tengah modifikasi dengan nilai $\mathrm{p}=0,000$ $(\mathrm{p} \leq 0,05)$ (2) terdapat peningkatan keseimbangan dinamis pada kelompok latihan propriosetif dengan nilai $\mathrm{p}=0,012(\mathrm{p} \leq 0,05)$. (3)Tidak ditemukan perbeda signifikan pada perubahan keseimbangan dinamis baik pada kelompok latihan tari maupun kelompok latihan proprioseptif yang ditunjukkan dengan nilai $\mathrm{p}=0,069(\mathrm{p} \geq 0,05)$. Simpulan: latihan tari Jawa Tengah modifikasi dan latihan proprioseptif sama-sama baik untuk meningkatkan keseimbangan dinamis lansia

Kata kunci: keseimbangan dinamis, tari Jawa Tengah modifikasi, latihan propriosepif 


\section{ABSTRACT}

Background: Being old is a natural thing that will be experienced by all humans. Along with the aging process there are many changes in the systems of the human body, include the musculoskeletal, nerves, cardiovascular, and the senses. These changes give impact on disorders in the elderly such as balance disorders, coordination disorders, and cognitive disorders that leads to various problems in the elderly such as increasing risk of falls, decreasing of activity performance and productivity or even to death. The biggest problem on elderly is balance. Best exercise to increase balance in elderly is the dynamic activity such as modified Central Javaneese dance and the proprioceptive exercise. Objective: this study will examine the differences between modified Central Javanese dance and proprioceptive training in improving dynamic stability of the elderly. Method: study was conducted on an elderly community namely the Simeon-Hanna community in the Maria Assumpa Klaten Church. In this study there were two groups: the modified Central Java dance group and the proprioceptive exercise group. Exercises are carried out twice a week for 8 weeks of a period with a 55 minutes for each exercise session. Balance and risk of falls measured using the TUG test. Result: as the study completed it was found that: (1) dynamic balance improvement was obtained in the modified Central Java dance group with $\mathrm{p}$ value $=0.000(\mathrm{p} \leq$ $0.05)$, (2) proprioseptive exercise improves dynamic balance with a value of $\mathrm{p}=0,012(\mathrm{p} \leq 0.05)$. (3) No significant differences found in dynamic changes between the dance group and the proprioceptive training with $p=0.069(\geq 0.05)$.

Keywords: dynamic balance, modified Central Javanese dance, proprioseptive exercise

\section{PENDAHULUAN}

Lansia (lanjut usia) adalah seseorang yang mencapai usia 60 tahun ke atas ${ }^{1}$. World Health Orgaisation (WHO) menyatakan bahwa prosentase penduduk lansia di kawasan Asia Tenggara mencapai $8 \%$ dari jumlah penduduk atau sekitar 142.000 jiwa dan akan meningkat 3 kali lipat pada tahun $2050^{2}$. United Nations $(U N)$, Department of Economic and Social Affairs , Population Division (2017) mengemukakan bahwa penduduk lansia di Indonesia pada tahun 2017 adalah 23,66 juta jiwa, meningkat pada tahun 2020 hingga mencapai 27,08 juta Pada tahun 2025 diprediksi meningkat menjadi 33.69 juta, tahun 2030 sejumlah 40,95 juta dan tahun 2035 mencapai 48,19 juta jiwa ${ }^{3}$.

Struktur suatu negara dikatakan tua jika mempunyai penduduk lansia dengan populasi di atas $7 \%$. Komposisi penduduk tua bertambah dengan pesat baik di negara maju maupun negara berkembang karena dipengaruhi oleh penurunan angka fertilitas (kelahiran), dan mortalitas (kematian) serta peningkatan angka harapan hidup (life expectancy). Keadaan ini dipengaruhi oleh beberapa faktor misalya: perbaikan status gizi dan sanitasi, peningkatan pelayanan kesehatan serta tingkat pendidikan dan sosial ekonomi yang semakin baik ${ }^{2}$. BPS memperkirakan bahwa usia harapan hidup penduduk Indonesia terus mengalami peningkatan, di mana pada 2045 - 2050 ratarata usia harapan hidup adalah 77,6 tahun ${ }^{4}$.

Tingginya jumlah penduduk lansia menjadi tantangan untuk mengatasi persoalan yang biasa dihadapi lansia baik permasalahan fisik, psikis maupun sosial. Manifestasi dari proses penuaan pada makhluk hidup secara umum adalah terjadinya penurunan secara bertahap pada kapasitas untuk keberlangsungan proses anabolik atau untuk merespon perubahan lingkungan. Proses penuaan yang secara fisiologis disertai dengan penurunan fugsi organ kemudian menimbulkan gangguan-gangguan pada memori, kecerdasan (kognitif), fungsi gerak (motoris) dan rasa (sensoris), serta gangguan keseimbangan dan koordinasi ${ }^{5}$. 
Penurunan kapasitas aerobik dan tingkat akifitas fisik pada lansia dapat menyebabkan perubahan pada pola jalan (gait) dan kesimbangan. Keadaan ini akan mengarah pada peningkatan resiko jatuh dan adanya impairment pada kapasitas fungsional lansia ${ }^{6}$. Kejadian jatuh adalah hal yang biasa terjadi dalam masyarakat. Permasalahan kesehatan terkait riwayat jatuh (misalnya fraktur atau benturan kepala) berkontribusi pada makin tingginya biaya perawatan masalah lansia ${ }^{7}$.

Sebagian besar faktor resiko jatuh pada lansia adalah akibat dari kelemahan otot dan penurunan kesimbangan serta gangguan pola jalan ${ }^{8}$. Gangguan keseimbangan dan kejadian jatuh umumnya dipengaruhi beberapa faktor yang saling berinteraksi dengan masalah lingkungan. Penuaan juga berkaitan dengan fungsi proprioseptif yang menurun, adanya degenerasi sistem vestibuler, melambatnya refleks posisi, dan penurunan kekuatan otot yang amat penting dalam memelihara postur ${ }^{9}$.

Kejadian jatuh atau ketakutan akan mengalami jatuh mengakibatkan pembatasan aktifitas lansia yang kemudian berdampak pada semakin menurunnya fungsi-fungsi tubuh, sehingga permasalahan akan semakin kompleks. Karena itu diperlukan tatacara yang sesuai untuk menangani persoalan resiko jatuh pada lansia, yang hendaknya benar-benar tepat sasaran (targeted), spesifik dan progresif ${ }^{10}$.

Latihan yang direkomendasikan untuk perbaikan keseimbangan dan pencegahan resiko jatuh adalah latihan aktifitas dinamis (dynamic activities). Latihan ini melatih pemusatan keseimbangan sementara tungkai bawah melakukan gerakan. Latihan ini bersifat fungsional, dan meliputi beberapa unsur gerakan seperti meraih, berputar, berdiri, dan naik tangga ${ }^{11}$. Salah satu di antaranya adalah latihan dengan gerakan tarian.

Latihan tari dapat meningkatkan kemampuan fungsional, koordinasi, keseimbangan,fleksibilitas serta kecepatan gerak ${ }^{12}$. Terapi dengan menari membantu merangsang sistem somatik, emosional dan persepsi pasien. Dalam satu sesi latihan terapis harus menemukan keseimbangan antara kondisi fisik dan emosi pasien ${ }^{13}$. Latihan dengan tarian adalah sesuatu yang menyenangkan bagi lansia. Latihan dengan tarian memiliki peran penting untuk meningkatkan keseimbangan pada lansia 12

Proprioseptif dapat dipengaruhi oleh tingkat aktifitas regular seseorang. Proprioseptif dapat dilatih dan latihan proprioseptif secara rutin bermanfaat untuk memulihkan dan meningkatkan keseimbangan. Proprioseptif dapat diartikan sebagai input neural kumulatif pada susuan syaraf pusat yang berasal dari ujung persyarafan khusus disebut mechanoreseptor yang terdapat dalam persendian, kapsul sendi, ligamen, otot, tendo, dan kulit. Fungsi proprioseptif menurun sejalan dengan bertambahnya usia, ini terkait adanya perubahan fungsi pada muscle spindle sehingga terjadi penurunan kemampuan pemrosesan input sensoris, serta penurunan performa neuromuskuler ${ }^{14}$. Adanya penuruan proprioseptif pada lansia bisa jadi merupakan faktor yang berkontribusi pada kejadian jatuh.

Berdasarkan pemikiran tersebut maka dalam penelitian ini akan dikaji perbedaan pengaruh pemberian latihan gerak tari Jawa Tengah modifikasi dan latihan proprioseptif terhadap keseimbangan dinamis lansia. Penelitian terdahulu telah menemukan bahwa kedua intervensi tersebut bermanfaat untuk memperbaiki keseimbangan dinamis sehingga dapat mengurangi resiko jatuh lansia, akan tetapi perbandingan efektifitasnya belum diketahui.

\section{METODE PENELITIAN}

Penelitian ini menggunakan metode eksperimental murni dengan rancangan penelitian two groups pre and post test design. Tujuan penelitian ini untuk mengetahui pengaruh latihan tari Jawa Tengah modifikasi dibandingkan dengan latihan proprioseptif terhadap peningkatkan keseimbangan dinamis lansia. Subjek penelitian dibagi menjadi dua kelompok yaitu kelompok I yang mendapatkan 
perlakuan latihan dengan gerakan tari Jawa Tengah modifikasii dan kelompok II dengan perlakuan berupa latihan proprioseptif.

Penelitian ini dilaksanakan di Wilayah Paroki Gereja Maria Assumpta Klaten dengan subjek penelitian adalah anggota paguyuban lansia Simeon-Hanna. Latihan dilakukan semiggu 2 kali selama 8 minggu. Waktu penelitian adalah bulan Maret - April 2019. Intervensi diberikan setiap hari Selasa dan Jumat pukul 07.00 -09.00 di Gereja Maria Assumpta Klaten. Keseimbangan dinamis lansia diukur dengan Time Up and Go (TUG) Test.

\section{HASIL PENELITIAN}

\section{Data Karakteristik Subjek}

Tabel 1

Data demografi subjek

\begin{tabular}{ccc}
\hline \multirow{3}{*}{ Variabel } & Kelompok & Kelompok \\
& latihan tari & proprioseptif \\
$\mathrm{n}=12$ & $\mathrm{n}=14$
\end{tabular}

Jenis

kelamin

Pria /\%

$5 / 41,67$

$4 / 28,57$

Wanita / \%

$7 / 58,33$

$10 / 71,43$

Usia (tahun) $68.92 \pm 4.03 \quad 69,5 \pm 5,47$

Hasil deskripsi karakteristik subjek penelitian meliputi: data gender dan kelompok usia subjek penelitian. Dari tabel 1 tersebut bisa diketahui bahwa pada kedua kelompok mayoritas sampel adalah perempuan yaitu $58,33 \%$ pada kelompok latihan tari dan 71,43 pada kelompok latihan proprioseptif. Sedangkan rata-rata umur subjek pada kelompok latihan tari adalah 68,92 sedangkan pada kelompok latihan proprioseptif 69,5 .

\section{Data Hasil Pengukuran Tes TUG}

\section{Tabel 2}

$\begin{array}{ccc}\text { Data deskripsi hasil pengukuran TUG } \\ \begin{array}{c}\text { Kelompok } \\ \text { latihan tari } \\ (\mathrm{n}=12)\end{array} & & \begin{array}{c}\text { Kelompok latihan } \\ \text { proprioseptif } \\ (\mathrm{n}=14)\end{array} \\ { \pm \text { SD }} } & & \text { Mean } \pm \text { SD }\end{array}$

\begin{tabular}{ccc} 
Pre & $11,24 \pm 1,70$ & $10,18 \pm 1,91$ \\
Post & $9,23 \pm 1,78$ & $8,96 \pm 1,75$ \\
Selisih & $2,07 \pm 1,36$ & $1,23 \pm 1,07$ \\
\hline
\end{tabular}

Berdasarkan hasil uji beda pada tabel 2, rata-rata keseimbangan dinamis pada kelompok lansia yang diberikan latihan tari jawa modifikasi adalah sebesar 11,24 detik sedangkan pada kelompok lansia yang akan diberikan latihan propioseptif, nilai rata-rata keseimbangan dinamisnya adalah sebesar 10,18 detik. Hal ini menunjukkan bahwa secara deskriptif, nilai rata-rata pada kedua kelompok tidak jauh berbeda. Tabel tersebut juga menampilkan bahwa rata-rata keseimbangan dinamis setelah perlakuan selama 14 kali pada kelompok latihan tari jawa adalah sebesar 9,23 detik sedangkan pada kelompok latihan propioseptif, nilai rata-rata keseimbangan dinamisnya adalah sebesar 8,96 detik. Selisih penurunan pada kelompok latihan tari lebih besar (2,01 detik) daripada selisih penurunan pada kelompok latihan proprioseptif $(1,23$ detik).

\section{Uji Normalitas dan Homogenitas}

Hasil uji yang ditunjukkan pada tabel 3 berikut, diperoleh hasil bahwa data telah memenuhi asumsi normalitas dan homogenitas, sehingga pengujian dilakukan secara parametrik dengan uji beda $t$ tidak berpasangan (independent sample t test).

Tabel 3

Hasil uji normalitas dan homogenitas

\begin{tabular}{ccc}
\hline \multirow{2}{*}{ Kelompok } & $\begin{array}{c}\text { Saphiro } \\
\text { Wilk } \\
\text { Test }\end{array}$ & $\begin{array}{c}\text { Lavene's } \\
\text { Test }\end{array}$ \\
\cline { 2 - 3 } & $p$ & $p$ \\
\hline Latihan Tari & 0,536 & 0,153 \\
Latihan & 0,560 & \\
Proprioseptif & & \\
\hline
\end{tabular}




\section{Uji Pengaruh Hasil Pengukuran Keseimbangan Dinamis Lansia}

Tabel 4

\begin{tabular}{|c|c|c|c|}
\hline \multicolumn{4}{|c|}{ Hasil uji beda kedua kelompok } \\
\hline \multirow{2}{*}{ Intervensi } & \multicolumn{2}{|c|}{$\begin{array}{c}\text { Mean } \pm \text { SD } \\
(\mathrm{mg} / \mathrm{dL})\end{array}$} & \multirow{2}{*}{$\begin{array}{l}\text { Nilai } \\
P\end{array}$} \\
\hline & Pre & Post & \\
\hline $\begin{array}{c}\text { Latihan tari Jawa Tengah } \\
\text { modifikasi }\end{array}$ & $11,24 \pm 1,70$ & $9,23 \pm 1,78$ & 0,000 \\
\hline \multirow[t]{2}{*}{ Latihan proprioseptif } & $10,18 \pm 1,91$ & $8,96 \pm 1,75$ & 0,012 \\
\hline & & 0,694 & \\
\hline
\end{tabular}

Tabel 4 menunjukkan $p$ value yang diperoleh dari hasil pengujian pada kelompok tari adalah $0,000 \quad(\leq 0,05)$. Hasil uji pada kelompok latihan proprioseptif adalah 0,012 ( $\leq$ $0,05)$ sehingga Ho ditolak dan dan disimpilkan bahwa baik pada kelompok latihan tari maupun kelompok latihan proprioseptif terdapat perubahan yang signifikan dalam keseimbangan dinamis lansia setelah dilakukan intervensi sebanyak 14 kali. Sedangkan $p$ value dari uji beda akhir antara kedua kelompok diperoleh $0,694(\geq 0,05)$ sehingga Ho diterima dan disimpulkan bahwa tidak ada beda signifikan pada keseimbangan dinamis antara kedua kelompok.

\section{PEMBAHASAN}

\section{Modifikasi Latihan Tari Jawa Tengah Meningkatkan Keseimbangan Dinamis Lansia}

Hafstrom et al (2015) mengemukakan bahwa program latihan pencegahan jatuh yang meliputi latihan mobilisasi dan kebugaran tubuh telah berhasil menurunkan angka kejadian jatuh pada lansia sebesar 35\%-54\% ${ }^{15}$. Latihan-latihan ini dilakukan baik secara perseorangan, dalam kelompok maupun kombinasi dari keduanya yang dilakukan beberapa kali seminggu dengan target latihan kekuatan dan keseimbangan, terkadang ditambah dengan latihan endurance seperti berjalan
Mierzwa et al (2016) mengemukakan latihan tari (dance therapy) secara signifikan dapat meningkatkan ketrampilan keseimbangan (balancing skills) pada wanita lansia. Hal ini disebabkan karena dalam gerakan tari meliputi stimulasi terhadap unsur-unsur penjagaan keseimbangan yaitu kontrol visual, sistem somatosensori serta sistem vestibular. Pada latihan menari dibutuhkan konsentrasi dan kemampuan untuk mengontrol perpindahan berat badan, gerak ayun pergelangan kaki serta perubahan variasi pola berdiri antara kaki rapat dan kaki melebar ${ }^{12}$.

Menari merupakan aktifitas yang memerlukan penjagaan keseimbangan yang baik. Menjaga keseimbangan tubuh erat berhubungan dengan sistem kontrol postural yang meliputi fungsi-fungsi motorik, sensorik dan sistem persarafan secara umum ${ }^{16}$. Latihan menari secara bersamaan merangsang komponen-komponen keseimbangan yaitu penglihatan (visual), pendengaran (auditory) dan input perifer.

Terhadap komponen penglihatan (visual), aktifitas menari membuat subjek harus melihat contoh gerakan yang diberikan, mengamati lingkungan sekitar sehingga dapat mengarahkan gerakan dengan leluasa, serta menentukan arah gerakan yang benar sebagaimana tuntutan gerakan yang diberikan dalam instruksi. Dengan kata lain untuk aktifitas ini mata menyediakan gambaran visual tentang letak tubuh sehingga tubuh dapat beradaptasi terhadap perubahan yang ada di lingkungan dengan cara mengaktifkan sistem muskuloskeletal untuk bekerja secara sinergis mempertahankan keseimbangan tubuh.

Terhadap komponen pendengaran (auditory), aktifitas menari menuntut subjek bisa menyesuaikan gerakan dengan musik pengiring. Telinga sebagai organ pendengaran tidak saja berfungsi untuk mendengarkan musik, tetapi kemudian memiliki peran penting dalam menjaga keseimbangan selama menari dengan menyediakan informasi untuk beberapa level. Organ otolitik (utricle dan succule) menyediakan informasi tentang posisi statis 
kepala, Kanalis semisirkularis menginformasikan tentang gerakan kepala, sedangkan pendengaran memberikan informasi tentang lokasi seseorang terhadap lingkungan sekitar. Informasi ini kemudian disusun dan diolah di brain stem dan cerrebelum. Selanjutnya pesan disampaikan ke mata supaya bisa mempertahankan pandangan yang stabil selama pergerakan kepala (vestubulo-oculo reflex); juga ke korteks dan spinal cord untuk memerintahkan dan mengontrol supaya otot postural (anti grafitasi) bekerja ${ }^{17}$.

Terhadap komponen input perifer, gerakan saat menari merupakan aktifitas yang kompleks dan melibatkan banyak sistem tubuh dengan komponen gerakan yang bervariasi dan posisi tubuh berubah setiap saat sesuai kebutuhan gerakan dan musik iringan. Informasi tentang posisi tubuh didapat dari saraf perifer (proprioseptif) dan mekanoreseptor di sendi. Informasi disampaikan melalui kolumna posterior ke spinal cord untuk diteruskan ke otak. Informasi ini akan direspon dengan perintah untuk mengaktifkan otot postural untuk menjaga tubuh tetap seimbang ${ }^{18}$.

Latihan menari adalah cara yang mudah, murah dan menyenangkan tetapi memberi dampak perubahan yang spesifik ${ }^{19}$. Homann (2010) mengemukakan bahwa therapy dengan tarian (dance therapy) menyediakan banyak peluang untuk meningkatkan kesadaran afektif dan regulasi emosional selama melakukan eksplorasi gerakan.

Gerakan yang khas dalam tari Jawa Tengah adalah mendhak (posisi berdiri dengan tubuh merendah) dan ndegeg (posisi tubuh tegak) dengan variasi gerak badan ngleyek (berayun ke salah satu sisi tubuh).

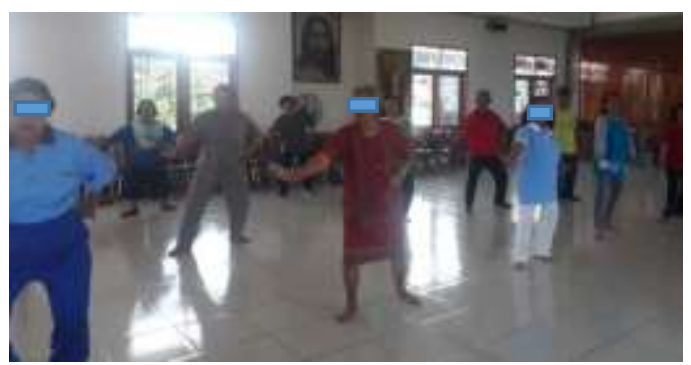

Gambar 1

\section{Pelaksanaan latihan tari Jawa Tengah modifikasi}

Gambar 1 menunjukkan salah satu gerakan dalam latihan tari Jawa Tengah modifikasi. Gerakan mendhak membuat otot quadriceps bekerja untuk mempertahankan posisi berdiri dengan lutut sedikit ditekuk dan otot-otot plantar fexor ankle bekerja untuk menjaga tumpuan tetap stabil. Gerakan ndegeg terjadi dengan kerjasama sinergis otot-otot postural. Menurut Irfan (2016) kelompok otot pada ekstremitas atas maupun bawah mempertahankan postur saat berdiri tegak juga mengatur keseimbangan tubuh dalam berbagai gerakan. Keseimbangan tubuh dalam berbagai posisi hanya akan terjadi jika respon otot-otot postural bekerja secara sinergi sebagai reaksi atas perubahan posisi, titik tumpu serta gaya gravitasi maupun alignment tubuh. Kerja otot yang sinergi artinya respon yang tepat (kecepatan dan kekuatan) dari otot terhadap otot lainnya dalam melakukan fungsi pada gerakan tertentu ${ }^{20}$.

Gerakan ngleyek merupakan jenis gerakan dalam tari Jawa Tengah dimana tubuh mengayun ke salah satu sisi tanpa melangkah. Latihan tari yang memberikan pengaruh terhadap pengontrolan perpindahan berat badan serta gerakan ayun ankle, perubahan antara berdiri dengan kaki rapat (narrow stance) dan kaki lebar (wide stance) untuk menyesuaikan perubahan base of support (BOS) secara kontinyu, gerakan rotasi yang dikendalikan oleh trunk serta gerakan dorsi dan plantar flexi selama menari akan memberikan pengaruh terhadap elemen sensorimotor yang penting yang berperan pada perbaikan keterbatasan stabilitas. Perbaikan stabilitas dapat dipengaruhin oleh peningkatan putaran fleksiekstensi ankle, range of motion (ROM) ankle, strategi perbaikan gerak, maupun sensori integrasi.

Latihan tari Jawa Tengah modifikasi yang merupakan pengembangan dari tari tradisional Jawa Tengah dapat menjadi alternatif latihan yang baik, dan sekaligus memiliki nilai lebih 
karena memanfaatkan warisan budaya untuk peningkatan kemampuan fungsional lansia. Besarnya minat lansia untuk mengikuti latihan tari bisa dimanfaatkan untuk menjaga kesehatan, terutama untuk keseimbangan postural dan pencegahan resiko jatuh. Sejalan dengan pengaruh latihan menari yang dapat mengatasi keterbatasan stabilitas, para lansia kemudian juga akan mampu melakukan aktifitas sehari-hari dengan lebih efisien serta memberikan kemandirian dan rasa aman yang lebih besar. Hal ini berdampak pada peningkatan kualitas hidup lansia ${ }^{12}$.

\section{Latihan Proprioseptif Meningkatkan Keseimbangan Dinamis Lansia}

Hasil uji beda kelompok latihan proprioseptif didapat $p=0,012(\leq 0,05)$. Hal ini menunjukkan bahwa keseimbangan sebelum dan sesudah lansia mendapatkan intervensi sebanyak 14 kali mengalami perubahan yang signifikan. Kesimpulan yang didapat adalah latihan proprioseptif dapat meningkatkan keseimbangan dinamis pada lansia.

Fungsi proprioseptif mengalami penurunan sejalan pertambahan usia, akan tetapi aktifitas fisik dapat menghambat penurunan ${ }^{14}$. Aktifitas fisik yang dilakukan secara rutin dapat meningkatkan representasi kortikal sendi yang berpengaruh pada peningkatan proprioseptif sendi. Latihan proprioseptif dapat meningkatkan kecepatan dan kontrol posisi gerak tubuh, serta sensor posisi sendi. Akurasi proprioseptif meningkat setelah diberikan pembelajaran motorik (motor learning) ${ }^{21}$. Adapun rangkaian latihan proprioseptif yang digunakan merujuk pada rumusan latihan oleh Kyra Oliver (2016) yang sudah dimodifikasi, terdiri dari: latihan table top untuk sisi kiri dan kanan dengan ditahan selama 3-5 detik dan repetisi sebanyak 10 kali untuk masing-masing sisi dengan perkiraan waktu latihan ini adalah10 menit; latihan single leg stance, berdiri dengan mengangkat salah satu tungkai setinggi 90 derajad dan ditahan selama 3-5 detik dan repetisi sebanyak 5 kali untuk masing-masing tungkai dengan perkiraan waktu latihan 10 menit; latihan cross over walk (berjalan ke depan dengan kaki menyilang satu sisi atas yang lain sejauh 5 langkah, lalu mundur ke titik awal dilanjutkan berjalan ke samping sejauh 15 langkah), dilakukan repetisi 5 kali untuk masing-masing sisi dengan perkiraan waktu untuk sesi ini adalah 15 menit; serta gerakan squat bertahap (pada posisi squat posisi badan diredahkan perlahan) dan ditahan 3-5 detik dengan repetisi 5-10 kali. Perkiraan waktu sesi ini 10 menit
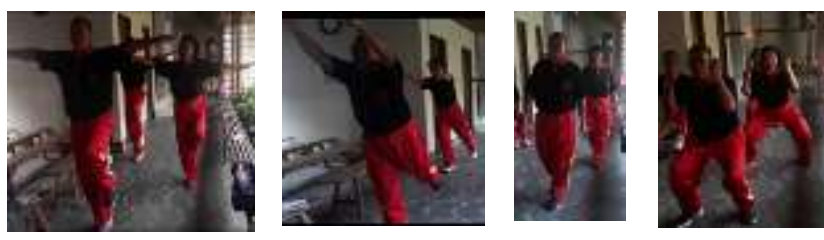

Gambar 2

Pelaksanaan latihan proprioseptif

Mekanisme proprioseptif diartikan sebagai mekanisme rasa posisi dan gerak dimana gerakan otot dapat disesuaikan dengan derajat akurasi yang tinggi serta keseimbangan yang terjaga. Pengaruh latihan proproseptif terhadap keseimbangan dijelaskan bahwa latihan tersebut akan mengaktifkan sistem proprioseptif dengan melatih kembali jaras aferen. Selanjutnya sistem proprioseptif akan menyampaikan informasi ke otak tentang posisi tubuh terhadap keadaan di sekitarnya (eksternal) serta posisi antara segmen dalam tubuh (internal) melalui reseptor-reseptor di dalam otot, ligament, sendi, tendon, serta kulit seluruh tubuh, terutama reseptor yang ada pada kolumna vertebralis dan tungkai. Informasi dapat berupa tekanan, posisi sendi maupun ketegangan, panjang dan kontraksi otot ${ }^{22}$.

Latihan akan mengaktifkan informasi tentang posisi gerak dan refleks muskular yang berperan pada kestabilan dinamis sendi. Tujuan latihan adalah melatih kembali jaras aferen untuk mengembangkan sensasi gerakan pada sendi serta mengaktifasi motorik di sistem saraf pusat. Hal ini penting dilakukan karena akan memacu umpan balik proprioseptif sehingga 
dapat meningkatkan dan mempertahankan stabilitas fungsional sendi.

Ribeiro dan Oliveira (2007)

mengemukakan bahwa level peningkatan proprioseptif perifer berhubungan dengan perubahan pada muscle spindle. Tidak ada bukti yang menunjukkan bahwa latihan dapat meningkatkan jumlah mekanoreseptor, tetapi ada bukti yang menunjukkan bahwa latihan fisik berpengaruh terhadap adaptasi morfologis pada mekanoreseptor utama yang terlibat dalam proprioseptif yaitu muscle spindle. Latihan dapat mempengaruhi adaptasi muscle spindle pada level mikro, serabut otot intrafusal juga menunjukkan adanya perubahan metabolik, dan pada tingkat makro keadaan respon stretch reflex menurun dan amplitudo meningkat. Latihan fisik yang meningkatkan kekuatan otot dapat juga meningkatkan proprioseptif. Peningkatan kekuatan otot karena latihan dapat memacu kontrol gerakan yang lebih baik dan konsekuensinya dapat mempengaruhi proprioseptif sendi pada saat menumpu berat badan $^{14}$.

\section{Latihan Tari Jawa Tengah Modifikasi Tidak Lebih Meningkatkan Keseimbangan Dinamis Lansia daripada Latihan Proprioseptif}

Secara statistik pemberian latihan tari Jawa Tengah modifikasi tidak lebih baik dari latihan proprioseptif dalam meningkatkan keseimbangan dinamis pada lansia meskipun secara deskriptif latihan tari Jawa Tengah Modifikasi memberikan pengaruh lebih besar $(2,01)$ daripada latihan proprioseptif $(1,23)$. Dengan demikian dapat disimpulkan bahwa latihan tari Jawa modifikasi dan latihan proprioseptif yang diberikan pada subjek lansia memiliki pengaruh sama baiknya terhadap peningkatan keseimbangan dinamis mereka.

Komponen-komponen yang dipengaruhi oleh latihan tari antara lain keseimbangan, koordinasi, kecepatan gerak. kekuatan otot, kelenturan dan daya ingat. Sedangkan komponen yang dapat dipengaruhi dengan latihan proprioseptif meliputi keseimbangan, kontrol gerak dan kekuatan otot. Secara teori dengan lebih banyaknya komponen yang terdampak oleh latihan tari maka semestinya hasil pengukuran keseimbangan dinamis lansia pada kelompok tari juga lebih baik. Namun demikian penelitian ini membuktikan bahwa tidak ada perbedaan berarti antara hasil perlakuan dengan latihan tari dan latihan proprioseptif. Kondisi tersebut dipengaruhi beberapa hal, antara lain sebaran jenis kelamin subjek yang tidak merata pada kedua kelompok, yang mana pada kelompok latihan tari prosentase subjek berjenis kelamin laki-laki lebih besar $(41,67 \%)$ daripada subjek laki-laki pada kelompok proprioseptif $(28,57)$. Hal ini berkaitan dengan minat terhadap bentuk latihan, di mana secara alamiah biasanya perempuan lebih menyukai kegiatan menari daripada laki-laki ${ }^{23}$. Adanya prosentase subjek laki-laki yang lebih besar pada kelompok tari membuka kemungkinan terpengaruhinya pelaksanaan latihan tari sehingga hasil pengukuran akhir juga mungkin terpengaruh.

Perbedaan lokasi latihan juga mempengaruhi hasil penelitian, yang mana karena keterbatasan tempat kelompok latihan tari harus berlatih di aula di lantai 2 gedung sehingga subjek harus menaiki tangga untuk menuju tempat latihan, sedangkan kelompok latihan proprioseptif berlatih di halaman depan yang lebih mudah dijangkau. Hal ini mungkin memberikan dampak karena latihan yang dilakukan di tempat yang lebih jauh dengan medan yang lebih berat akan mengurangi semangat dan minat untuk berlatih, di samping kelelahan yang timbul sebelum latihan.

Terdapat pula hal-hal yang tidak bisa dikontrol oleh peneliti seperti kebiasaan olahraga dan aktifitas keseharian, kondisi lingkungan tempat tinggal serta aktifitas sosial. Kebiasaan olahraga dan aktifitas fisik di luar kegiatan yang dilakukan bersama dalam program ini mungkin berpengaruh terhadap kapasitas aerobik subjek secara umum. Kondisi lingkungan tempat tinggal subjek yang beragam juga dapat berpengaruh pada hasil pengukuran. Subjek yang memiliki tempat tinggal dengan pengaturan ruang yang rumit atau memiliki banyak ruangan atau lebih dari satu lantai lebih 
terbiasa dengan aktifitas fisik sehingga kapasitas aerobiknya juga berbeda. Demikian juga aktifitas sosial memiliki dampak pada kondisi fisik dan emosi subjek. Semakin tinggi beban aktifitas social subjek maka tingkat stress psikologisnya juga lebih tinggi. Hubungan dengan orang lain yang dilakukan seseorang diluar daftar keluarganya menyediakan banyak sumber stress ${ }^{24}$.

\section{KETERBATASAN PENELITIAN}

1. Tidak dilakukan pengukuran TUG secara bertahap selama masa perlakuan

2. Tidak ada skrining pola aktifitas pada awal penelitian

\section{SIMPULAN}

Dari uraian tentang penelitian di atas dapat disimpulkan:

1. Latihan tari Jawa Tengah modifikasi dapat meningkatkan keseimbangan dinamis geriatri

2. Stimulasi proprioseptif dengan latihan berpengaruh pada peningkatan balans dinamis lansia

3. Tari Jawa Tengah modifikasi dan latihan proprioseptif sama baiknya untuk membuat peningkatan balans dinamis pada geriatri

\section{DAFTAR PUSTAKA}

1. Undang-Undang No 13. (1998). Kesejahteraan Lanjut Usia. Jakarta: //http:www.dpr.go.id/uu/uu98/uu_98_13 .pdf.

2. Kementrian Kesehatan RI. (2013). Populasi Lansia Diperkirakan Terus Meningkat Hingga Tahun 2020. Kementrian Kesehatan, 1-2.

3. Pusdatin Kementrian Kesehatan RI. (2017). Analisis Lansia di Indonesia. Jakarta: Kemenkes RI.
4. Pusdatin Kementrian Kesehatan RI. (2014). Situasi dan Analisa di Idonesia di Indonesia. Jakarta: Kemenkes RI.

5. Lumbantobing (2005). Neurogeriatri. Jakarta: Balai Penerbit Fakultas Kedokteran Universitas Indonesia.

6. Lima, G. A. (2011). Balance and Aerobic Capacity of Independent Elderly: A Longitudinal Cohort Study. Rev Bras Fisioter, 15(4);272-7.

7. Allison, L. (2013). Participation Restriction, Not Fear of Falling, Predicts Actua Balance and Mobility Ability in Rural Community-Dwelling Older Adults. $J$ GeriatrPhysTher, JanMar;36(1);13-23.

8. Salminem, M. (2009). Effect of RiskBased Multifactorial Fall Prevention on Postural Balance in the CommunityDwelling Aged: A Randomized Control Trial. Archieve of Gerontology and Geriatrics 48, 22-27.

9. Munawwarah, M. \&. (2015). Pemberian Latihan pada Lansia Dapat Meningkatkan Keseimbangan dan Mengurangi Resiko Jatuh Lansia. Jurnal Fisioterapi Volume 15 No 1.

10. Skeleton, D. A. (1999). Exercise for Fall Management: Rationale for A Programme Aimed at Reducing Postural Instability. Physiotherapy Theory and Practice, 105-120.

11. Schubert, T. M. (2010). The Effect of Exercise Based Balance Intervention on Physical and Cognitive Performance for Older Adult: A Pilot Study. Journal of Geriatric Physical Therapy.

12. K.Filar-Mierzwa, M. D. (2016). The Effect of Dance Therapy on the Balance of Women Over 60 Years of Age: The Influence of Dance Therapy for The Elderly. Jurnal of Woman and Ageing.

13. Homann, K. B. (2010). Embodied Concept of Neurobiologyin Dance/MovementTherapy Practice. Am $J$ Dance Ther. 
14. Ribeiro, F. \&. (2007). Aging Effect on Joint Proprioception: The Role of Physical Activity in Proprioception Preservation. Eur Rev Aging Phys Act 4, 71-76.

15. Hafstrom, A. M. (2016). Improved Balance Confidence And Stability for Elderly After 6 Weeks of A Multimodal Self-Administered Balance Enhancing Program: A Randomized Single Crossover Study. Gerontology and Geriatric Medicine Vol 2, 1-13.

16. Mesquita, L. C. (2015). Effect of Two Exercises Protocols on Postural Balance of Elderly Woman: A Randomized Control Trial. BMC Geriatrics, 15;16.

17. Cayea, D. (2010). Falls and Gait Imbalance. In S. C. Durso, Oxford American Hndbook of Geriatric Medicine 6th Edtion (pp. 81-102). New York: Oxford University Press.

18. Huxham, F. G. (2001). Theoretical Consideration in Balance Assesment. Aust J PhysioTher 47, 89-100.

19. Serra MM, A. A. (2016). Balance and Muscle Strength in Elderly Women Who Dance Samba. Plos One.

20. Irfan, M. (2016). Keseimbangan pada Manusia. Artikel Publikasi Ilmah Ikatan Fisioterapi Indonesia, 1-2.

21. Oliver, K. (2014). 4 Proprioception Exerxercise to Improve Balance and Strength. Draxe.com.

22. Suhartono (2005). Panduan Gerontologi Tinjauan dari Berbagai Aspek. Jakarta: PT Gramedia Pustaka

23. Indriyani, P. D. (2016). Studi Komparasi Minat dan Belajar Seni Tari antara Siswa laki-Laki dan Siswa Perempuan di SMP Negri 6 Yogyakarta. Yogyakarta: Universitas Negri Yogyakarta.

24. Rakhmat, J. (2014). Psikologi Komunikasi. Bandung: Rosdakarya. 